be surveyed in detail. The faulty alinement of a railway has more than once been a source of serious expense to a colony, and its avoidance by ground surveys of several possible routes is not only a costly matter but also always entails the possibility of the best route being overlooked if a feasible one be found. For such a purpose no detailed work is required until the engineers have chosen the most useful route, which then of course has to be surveyed in detail. Air photography has also been used with success, particularly in the United States, in coastal surveys for the exploration of obstructions to navigation in deltaic waters and on rocky coasts. Aeroplanes have been employed by the government of Canada in surveying the distribution and movements of ice in Hudson Strait in connexion with the opening of the new trade route via Hudson Bay to Churchill, which is to be a wheat port for the west of Canada.

Air survey can also be used in the investigation of water-power development, and water storage for irrigation purposes. The feasibility of a power scheme based on the storage of water which necessitates the submergence of large areas of land can be ascertained by stereoscopic photographs. They provide the preliminary reconnaissance at a low cost and in a short time. The photographs taken for the preliminary investigations can then be used for the final plans merely by the addition of ground control. The location surveys required for electric power cables and pipe lines can rapidly be made from the air.

Air photography can also supply much useful information with regard to mineral resources. It cannot be used for detached geological survey, but it can give geological indications by means of land forms which will afford useful suggestions to the surveyor and point to localities where close investigation might be profitable. Air photographs of vegetation serve as a useful guide in a survey of soils and the possibilities of cultivation of various crops, and in forest survey they serve to indicate areas of value for commercial purposes. As a result of recent work in Northern Rhodesia, during which air surveys were extensively used, Mr. R. Bourne, of the Imperial Forestry Institute at Oxford, emphasised all these among other uses to which air photographs can be put.

The aeroplane has also been found useful in combating insect pests. Successful operations in the cotton fields of the United States prompted the Canadian authorities to try the experiment of scattering insecticides from an aeroplane over spruce forests in Nova Scotia. The first year's experiments were very promising.

There is, in fact, a wide scope for the use of aeroplanes in all parts of the Empire quite apart from the transport facilities they provide. They afford another example of the value of scientific application in the development of the resources of new lands, and can be employed for many useful purposes at comparatively small cost.

\section{Evolution and Fundamentalism.}

TTHE illegitimate use of the minor discussions of scientific workers to cast doubt upon the whole question of evolution is well known and can be guarded against only by extreme caution in our words. This is illustrated in an article in the Catholic review, America (Nov. 10, 1928), entitled "Neanderthal-a Slippery Ancestor." The writer pits against each other the views of Hrdlička and Elliot Smith (with quotations from NATURE) regarding the significance of Neanderthal man in human evolution, and because a divergence of opinion exists, he suggests that science should be looked on askance. "Draw up to the curb of commonsense and Revelation," he says, . . . "because very often "scientists' are but a 'We-Too' gathering, all, despite their protestations of independent thinking, following some leader in beating the tomtom of Evolution." But, of course, on the fundamental question of evolution or non-evolution amongst all living things, including man, the two distinguished scientific workers named are in agreement.

While such articles show that the fire of dissent is still alight, a recent Daily Science News Bulletin, issued by Science Service of Washington, points to a distinct smouldering at the present time. In universities and other centres of higher education in Tennessee and elsewhere, anti-evolution legislation is " more honoured in the breach than in the observance," but in the lower schools, particularly in smaller places, no amount of theoretical freedom of teaching can prevent local school boards from rejecting candidates for positions when they do not approve of their theological views. Biologists have come to accept these two conditions as actualities of their profession.

Since the Scopes trial at Dayton, Tennessee, in 1925, no serious effort has been made to get a test case of the anti-evolution statutes in Tennessee or Mississippi, the only two States which have passed such laws up to now. Perhaps this is partly due to the indefiniteness of the law itself, for in its decision on the appeal of the Dayton case, the Tennessee Supreme Court rendered three distinct opinions, all of which left the interpretation of the law in a state of confusion. In spite of this enforced truce, it would be unwise, however, to imagine that the smoking flax of anti-evolutionism is anywhere near the quenching stage.

By an overwhelming majority Arkansas has adopted an anti-evolution law, so that it is now

No. 3086, VoL. 122] 
illegal in every tax-supported school of the State to teach that "man has ascended or descended from any lower order of animals." Furthermore, it is believed in well-informed circles in the United States that if similar anti-evolution laws were submitted to popular referendum in every other available State, the result would in every case be the same under present conditions. There are nineteen other States open to fundamentalist attack by way of initiative and referendum, and in due course each is to be tackled.

One of the present conditions with which the journal Evolution finds fault is the aloofness of the body of men of science. In Arkansas, according to a leading article, they kept silent, under the idea partly that " the way to defeat the anti-evolution law is to keep the people from finding out what evolution really means," and partly that what " the masses " think or believe is of no consequence. The first notion surely cannot be held by any true man of science, but the second is familiar enough. Yet it cannot be justified, for it indicates a lack of social responsibility, and may lead to a very real curtailment of the opportunities of science through the pressure of the very masses whose education is wilfully ignored.

The plea of the fundamentalist is a practical one-the old story of he who pays the piper calls the tune. The only way to meet such opposition is not by raking up an equal number of adverse votes, but by enlightenment, and that is a slow process unless the men of science as a body are prepared to leave the laboratory bench and go out into the wilderness preaching their gospel of truth and progress.

We are of opinion, however, that Evolution tends to follow a line of propaganda which must have unfortunate reactions. It must be assumed that the fundamentalists are sincere in their views. Sarcastic references and polemic articles can only embitter the contest. The old ideas have a strong hold and have behind them the sanction of ages: only by gentle stages can they be shaken, and the science propagandist must temper his wind to the shorn lamb of fundamentalist ignorance.

Nevertheless, the conclusion reached by Evolution is sound. If ignorance is to be dispelled before the mischief is done, " every opportunity should be utilised to educate the public as to what evolution means." "Not only through the class-room, but also through the platform, radio, movie, magazines, and newspapers, ten thousand spokesmen of science should lift their voices, so that an understanding of the method of science may replace popular superstition and bigoted belief." But are there ten thousand, nay, one thousand men of science, who can carry on the propaganda as it should be carried on to win a popular victory?

No. 3086, VoL. 122]

\section{Eugenics Now and Hereafter.}

(1) Organic Inheritance in Man. (University of Birmingham, Faculty of Medicine: William Withering Memorial Lectureship.) By Dr. F. A. E. Crew. Pp. xxviii +214 . (London and Edinburgh : Oliver and Boyd, 1928.) 12s. 6d. net.

(2) Being Well-Born : an Introduction to Heredity and Eugenics. By Prof. Michael F. Guyer. Second edition. Pp. $\mathrm{xv}+490+9$ plates. (London : Constable and Co., Ltd., 1928.) 21s. net.

TERE we have two more works added to the 1 long list, which claim to enlighten man on the facts of his inheritance and to indicate - at any rate in brief outline-how these facts may be applied to racial betterment. It has become a custom, almost a necessity, we might say, for every professor of biology, be he zoologist or botanist, to publish a treatise on eugenics. The subject has become fashionable, and his pupils demand instruction; the academic lectures are given, and later the book appears. In the beginning of last century, every medical man, from Erasmus Darwin downwards, held himself to be a trained biologist; in the latter half of the century every anatomist was ipso facto an anthropologist, and in this new century every biologist must of necessity publish his views on eugenics.

Biology and anthropology have survived this handling, and it may be anticipated that eugenics will do so likewise and become ultimately a definite discipline with well-defined frontiers, and its own independent academic laboratories, even if they remain in close association with those in which animal genetics, anthropology, medical research, and statistics are topics of investigation. No eugenic investigator can work effectively without some fundamental knowledge on these allied sciences ; but it is equally true that a worker in any isolated one of them is not of necessity an authority on eugenics as a science, although he may contribute material which will be of service to the eugenist.

(1) Dr. Crew's book on " Organic Inheritance in Man " embodies the subject matter of a course of lectures he gave in the University of Birmingham to medical men, and especially general practitioners, as the first William Withering Memorial lecture. To those who have read Morgan's writings at first hand, or even are familiar with Baur and Lenz's "Menschliche Erblichkeitslehre," there will be small difficulty in following the bulk of Dr. Crew's work. But to those who have not, we 